Marketing in Asia Group

Asian Journal of Business Research

Volume 10 Issue 2, 2020

ISSN 2463-4522 e-ISSN 1778-8933

DOI: $10.14707 /$ ajbr.200083

\title{
Antecedents of Innovation Capability and Firm Performance of Indonesian ICT SMEs
}

\author{
Dian Tauriana Siahaan \\ Indonesia International Institute for Life Sciences, Indonesia \\ Caroline Swee Lin Tan \\ School of Fashion and Textiles, RMIT University, Australia
}

\begin{abstract}
This paper aims to explore the antecedents of innovation capability and firm performance of ICT SMEs within clusters in Indonesia. A causal model was proposed and tested using Partial Least Squares (PLS). The findings reveal that innovation capability is a critical determinant of superior firm performance, while intellectual capital is its major contributor to innovation capability. Surprisingly, being spatially close in a specific location does not lead to the presence of innovation capability. Instead, firm performance is marginally and directly improved by grouping ICT firms nearby and promoting learning capability. In practice, placing firms together in a specific location does not create innovation capability unless it is in collaboration with the governments to improve current infrastructure and eliminate inefficient policies.
\end{abstract}

Keywords: Innovation Capability, Firm Performance, SMEs, ICT, Indonesia. 


\section{Introduction}

As the globalization has accelerated the pace of technological innovation, the government spending on research and development has increased to promote innovation in science and technology (OECD, 2019). As a result, firms need to develop innovation capability that can translate their resources into novel and useful new products, services, methods, or systems (Al-Kaouti et al., 2020). It has been postulated that the presence of innovation capability is critical to develop innovation (Hogan et al., 2011) because it affords firms flexibility to improve their products according to the changing expectations of markets in sustaining growth (Liu et al., 2018). Therefore, firms can enhance their firm performance through the transformation of their resources into valuable outcomes and firm competitive advantage (Martínez-Román, Tamaro \& Gamero, 2017).

Previous studies of innovation capability have mostly employed Resource-based View (RBV) and Dynamic Capabilities (DC) theories in explaining the antecedents of innovation capability and firm performance. The theory explains how firm resources and capabilities differentiate firm performance (Barney, 1991). Meanwhile, DC theory, which is an extension of the RBV theory, expands the process, routines and activities through which organizational resources can be transformed into capabilities to obtain sustainable competitive advantage (Eisenhardt \& Martin, 2000). Teece (2007) suggested that it is necessary to reveal the 'hidden' factors behind the transformation process from resources to capabilities. However, these two theories, do not address the issue of firms located in spatial proximity and how this may facilitate or hinder innovation capability. As Marshal (1925) proposed, benefits (e.g., reduced production costs, mobility of skilled labor, and collective learning) can accrue to firms by being located in a geographical proximity. Therefore, its prominence of spatial proximity in fostering innovation capability cannot be overlooked (Malmberg \& Maskell, 2002).

Based on the application of RBV and DC theories, previous work on innovation capability showed its connection between innovation capability with intellectual capital (Yeşil \& Doğan, 2019), learning capability (Alegre \& Chiva, 2008) and technology orientation (Salojärvi et al., 2015). However, little effort has been made to incorporate the role of interactions among actors in spatial proximity or a regional innovation network in influencing or hindering the presence of innovation capability (Bittencourt et al., 2018; Fitjar, Gjelsvik, \& Rodriguez-Pose, 2013; Piazza et al., 2019). It appears that a lack of research examining the extent to which interactions between actors in spatial proximity can shape local innovation capability (Bittencourt et al., 2018). Consequently, this study integrates an innovative milieu, which is described as the formal and informal relationships among actors in a defined region that shape local innovation capability through synergy and localized learning (Camagni, 1995), to investigate antecedents of innovation capability and firm performance of firms in a developing country. 
As a developing nation, Indonesia is transitioning from a predominantly agriculturebased economy to a more service-based orientation due to the increasing importance of knowledge economies (Republic Indonesia Masterplan, 2011). In this context, the contribution of the service sector contributed $43.4 \%$ of total GDP, whereas the agriculture and industry (e.g., construction, mining, etc.) sectors contributed $12.8 \%$ and $39.7 \%$ respectively. Compared to other Southeast Asian Countries, the added value of the service sector in Indonesia is the fourth highest after Singapore, Thailand, and Malaysia. Therefore, it is much higher than Brunei, Cambodia, Laos, and Vietnam (see Figure 1).

Figure 1: Sectoral Value Added to GDP (\%) per Country 2018

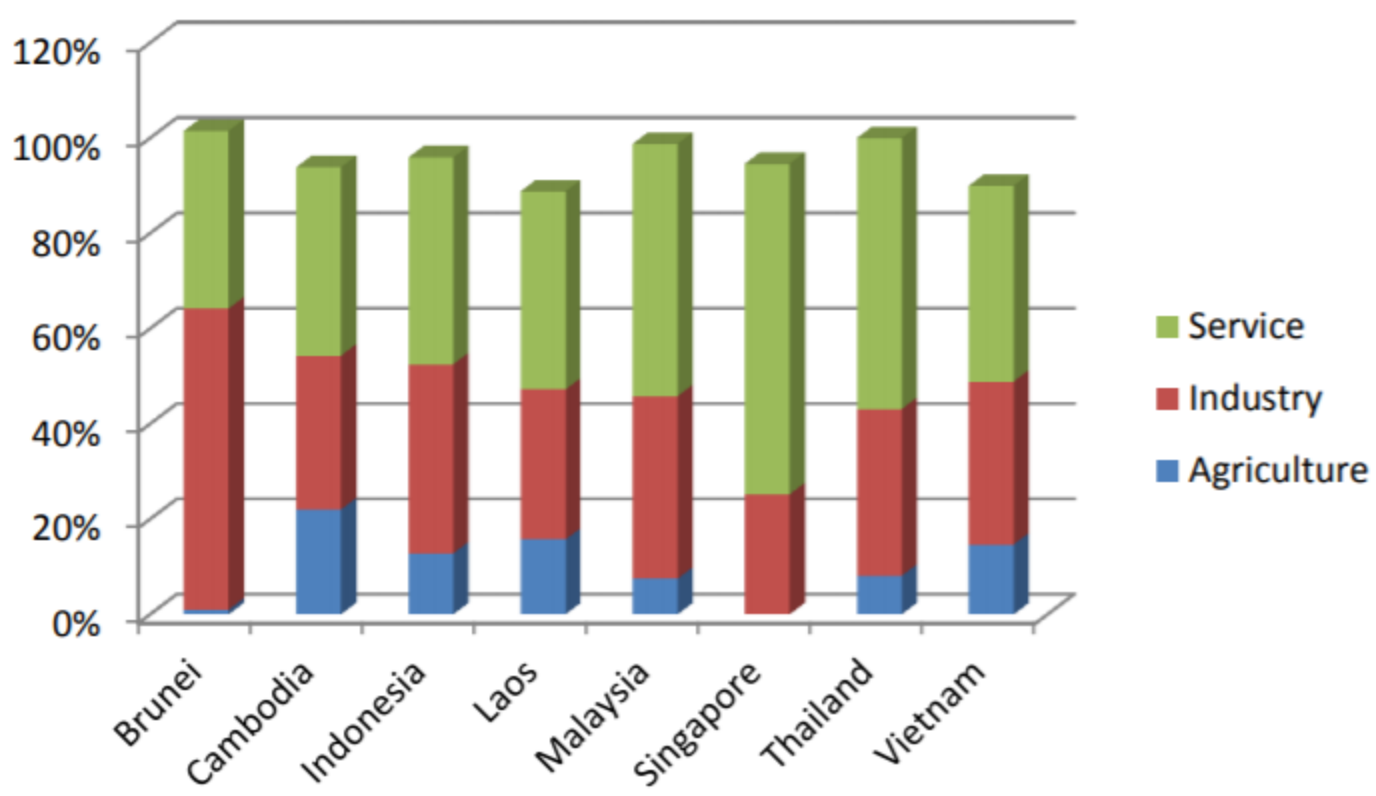

In light of the need to strengthen the service sector, the Indonesian government considers the Information and Communications Technology (ICT) sector to be a crucial industry as it enables the flow of goods and information required in trading and other economic activities. For this reason, the national government emphasized ICT as the backbone of the national master plan (Republic Indonesia Masterplan, 2011).

Developing countries have recognized that small and medium-sized enterprises (SMEs) contribute significantly to economic growth in employment and GDP (Zafar \& Mustafa, 2017). To promote innovation in the ICT industry, the Indonesian government currently collaborates with academia and business to support SMEs to generate innovations by establishing technology and science parks and innovation clusters. However, despite the substantial effort to develop ICT innovation in the country, the level of innovation in Indonesia is still significantly lower than that of Malaysia (Global Innovation Index, 2019). This led to a call to investigate the factors that determine innovation capability and firm performance in Indonesia, which is crucial for evidence-based guidelines for policy-makers and academia to enhance national innovation. Therefore, this study aims to explain the antecedents of innovation capability and business performance of Indonesian ICT SMEs and to 
provide answers to two research questions: (1) Do intellectual capital, learning capability, technology orientation and innovative milieu influence innovation capability and firm performance? And (2) Does innovation capability mediate the impact of intellectual capital, learning capability, technology orientation and innovative milieu on firm performance? The following section describes the underpinning theories and hypothesis development, followed by the research methodology adopted. The analysis, discussion and managerial implications of this study are presented before discussing conclusions, limitations and directions for future research.

\section{Theoretical Background and Research Hypotheses}

\section{Innovation Capability and Firm Performance}

Innovation capability is defined as the ability of a firm to transform its knowledge, capabilities and assets into new products, services, methods, organizational systems and management that can provide benefits to interested parties (Hogan et al., 2011). The capability to innovate can increase firm competitiveness by promoting product and service innovation, which contributes to national or international sales, market extension and organizational growth. Innovative firms integrate technological novelties into their systems and processes that can increase cost efficiency and added value (e.g., new design, new production techniques, etc.) (Martínez-Román, Tamayo \& Gamero, 2017).

Furthermore, firms need to outperform their rivals in coping with market uncertainty by sustaining their competitive advantage, which is also central for small firms in highly competitive business environments. Due to their liabilities, in size and resources, small firms can enhance their survival and growth in knowledge-based economies by developing a competitive advantage through their innovation capability. Firms with greater innovation capability can provide quick responses to changes in the marketplace by developing new approaches, or business models that can exploit opportunities available in the market and therefore obtain a sustainable competitive advantage (Al-Kalaouti et al., 2020). Consequently, small firms with high technology and innovation capability can advance their potential by exploiting external opportunities to produce products or services that are difficult to imitate for firms without these characteristics (Rasiah, Shahrivar \& Yap, 2016). Therefore, the following was proposed:

H1 Innovation capability positively and significantly influences firm performance.

\section{Intellectual Capital, Innovation Capability, and Firm Performance}

Intellectual capital is defined as the body of knowledge a company generates and uses to obtain advantages over its competitors (Subramaniam \& Youndt, 2005). To develop innovation capability, firms should utilize their knowledge resources embedded within their organizations (Teece, 2007), and they are sourced from human capital (e.g., employees), social capital (e.g., business networks) and organization 
capital (e.g., codified knowledge). Human capital is defined as the set of skills, knowhow and knowledge that are integrated into the employees of the firm (Subramaniam \& Youndt, 2005). Carmona-Lavado, Cuevas-Rodriguez, and Cabello-Medina (2013) suggested that unique ideas gained from employees, interaction with others (e.g., employees, clients) and organizational repository of knowledge may offer different perspectives for firms to advance their current services.

The second subset of intellectual capital is social capital, defined as the knowledge and capability derived from the interpersonal networks of a firm (Nahapiet \& Ghoshal, 1998). According to Liu et al. (2017), innovation capability requires partnerships. In this scenario, social capital plays an important role in developing innovation capability as social networks allow firms to assimilate external information to generate innovative products and services. The last subset of intellectual capital is organizational capital. This type of capital relates to all knowledge documented and codified in databases, manuals, formal structures or procedures and so forth (Youndt, Subramaniam \& Snell, 2004). In addition, it is derived from both coordinated action and routine innovation activities.

The integration of knowledge and coordinated action allows firms to diagnose what they have learned and resolve future actions that may be required. With reference to innovation capability and firm performance, firms need information that can be stored in their systems, structures, and procedures (Sivalogathasan, 2016). Investigating into the interactions among three elements of intellectual capital is regarded as crucial (Inkinen, 2015), because the interactions between employees and customers to identify customers' demands require the presence of social capital and human capital (Shih, Chang \& Lin, 2010). In addition, firms still need to develop innovation capability to transform their intellectual capital into improved firm performance (Lee, Yang \& Huang, 2019). Therefore, it was suggested that:

H2 Intellectual capital positively and significantly influences innovation capability.

H3 Intellectual capital positively and significantly influences firm performance.

H4 Innovation capability mediates the impact of intellectual capital on firm performance.

\section{Learning Capability, Innovation Capability, and Firm Performance}

Learning capability, also known as organizational learning capability (OLC) is defined as "the organizational and managerial characteristics that facilitate organizational learning process or allow an organization to learn" (Chiva, Alegre \& Lapiedra 2007, p. 225). It enables firms to be adaptive to changing environments and market uncertainty, and includes customer demands, turbulent competition or technological changes in generating new products or services (Alegre \& Chiva, 2008). 
Firms need to develop learning capability to improve the generation, dissemination and use of knowledge. Through this process, learning capability can promote creativity and more knowledge by collecting, distributing, and using employee knowledge (Chiva \& Alegre, 2009). The ideas produced through informal interaction among employees enable an atmosphere that triggers firm innovativeness (JerezGómez, Céspedes-Lorente \& Pérez-Valls, 2019). In general, firms with greater capability to learn have better opportunities to identify, exploit, and adapt to their rapidly changing environment (Jimenez-Jimenez \& Cegarra-Navarro, 2007). In this context, learning capability is considered to be a driver that enhances a firm's capability to offer better solutions for firm's existence and growth in the future (Camps et al., 2016). For example, learning capability enables firms to obtain, disseminate, and use the knowledge and information that arises in organizations. In addition, it facilitates the learning process within organizations and creates structures through which effective learning processes actualize new services (Guinot, Chiva \& Mallén, 2016). Therefore, firms possessing the ability to generate new knowledge and integrate it with different approaches can improve their business performance (Weerawardena et al., 2015). All of these benefits that come from learning capability may contribute to enhancing firm innovation capability and leading to improved firm performance (Guinot, Miralles, \& Chiva 2020). In this context, innovation capability plays a mediating role in explaining the impact of learning capability on firm performance (Gomez \& Wojahn, 2017; Sawean \& Ali, 2020). Thus, it is proposed that:

H5 Learning capability positively and significantly influences innovation capability.

H6 Learning capability positively and significantly influences firm performance.

H7 Innovation capability mediates the impact of learning capability on firm performance.

\section{Technology Orientation, Innovation Capability, and Firm Performance}

Technology orientation is the ability and determination of a firm to acquire and use technological skills in providing superior products and services to meet customer needs. This implies that firms can use their technical knowledge to deliver better technical solutions to fulfill customer demand (Gatignon \& Xuereb, 1997). Technologically proficient firms have more effective grounds to pursue innovation capability (Tseng, Chang \& Chen, 2019). According to Akman and Yilmaz (2008), efforts to advance a firm's technological capabilities will enhance its capability to innovate. This construct was chosen for this study because technology-driven companies can do better to create rare and difficult-to-replicate competitive advantages by providing their customers with excellent solutions (Hakala, 2011; Poudel, Carter \& Lonial, 2019). 
As businesses compete in a turbulent environment, there is a need to foster an organizational culture that is open to the adoption and diffusion of new technologies. Those with technological cultures provide resources for research and development and employ technologically competent staff to promote learning and creativity (Ritter \& Gemünden, 2014). Furthermore, it supports the existence of technological advances compatible with the concept of innovation (Hortinha, Lages \& Lages, 2011).

With reference to technology orientation, Barczak (1994) reported that firms with a strong focus on technology tend to develop a synergistic relationship between products and new markets. Those that develop a technological orientation increase their opportunities to improve performance. In addition, these organizations are more competent and flexible, allowing them to improve their current technology. These firms can develop innovations in their current markets or use their technologies to identify new markets. Hence, innovation capability is regarded as a mediator in elaborating the effect of technology orientation on firm performance (Tseng, Chan \& Chen, 2019), and it is proposed that:

H8 Technology orientation positively and significantly influences innovation capability.

H9 Technology orientation positively and significantly influences firm performance.

H10 Innovation capability mediates the impact of technology orientation on firm performance.

\section{Innovative Milieu, Innovation Capability, and Firm Performance}

The spatial proximity between actors improves their access to tangible and intangible resources (Mu et al., 2017). Firms can benefit from internal resources, reduced costs and develop better innovation capability by maximizing their resources through exchange and acquisition (Piazza et al., 2019). Despite challenges to the theory of innovative milieu, a company's location has been shown to affect how well it performs. Earlier studies in this domain have linked spatial proximity and its external interdependencies on innovation. The proximity allows companies to access the labour market, to share the input or resources and knowledge spill overs available within a region (Asheim, Grillitsch \& Trippl, 2016). Therefore, territorial models such as learning regions, industrial districts, or an innovative milieu provide the means through which spatial proximity promotes innovation (Camagni, 1995).

In general, an innovative milieu involves shared and active processes amongst actors in a given region to create productive inter-dependencies or a productive synergy that may lead to better performance (Doloreux et al., 2019). These social and economic relationships encourage the development and distribution of new knowledge needed to advance innovation. This process is particularly important for SMEs, since they depend on informal networking, trust and collective learning (Keeble, 2017). As firms 
develop connections with customers, suppliers, and institution, they can substantially benefit from important input present in the region for the accumulation of innovation capability (Lundvall, 2016). In addition, firms located in spatial proximity can benefit from interacting among actors present in the milieu, to collect information on the market, technology, training and consulting services, and R\&D grants. In this context, several researchers have suggested that an innovative milieu can improve the effectiveness of localized learning (Ferras-Hernandez \& Nylund, 2019). Therefore, innovation capabilities and activities are likely to be found in local environments with high interdependence between firms, institutions and related agencies (Gilbert, 2007). However, previous studies of the innovative milieu have not related spatial proximity to innovation capability and firm performance. Meanwhile, Gilbert (2007) suggested that innovation capabilities and activities are likely to be found in local environments where there is high interdependence between firms, institutions and related agencies since they can improve organizational performance (Belussi \& Hervas-Oliver, 2018). Therefore, it is hypothesized that:

H11 Innovative milieu positively and significantly influences innovation capability.

H12 Innovative milieu positively and significantly influences firm performance.

H13 Innovation capability mediates the impact of innovative milieu on firm performance.

Figure 1: Framework of Innovation Capability and Firm Performance of Indonesian ICT SMEs

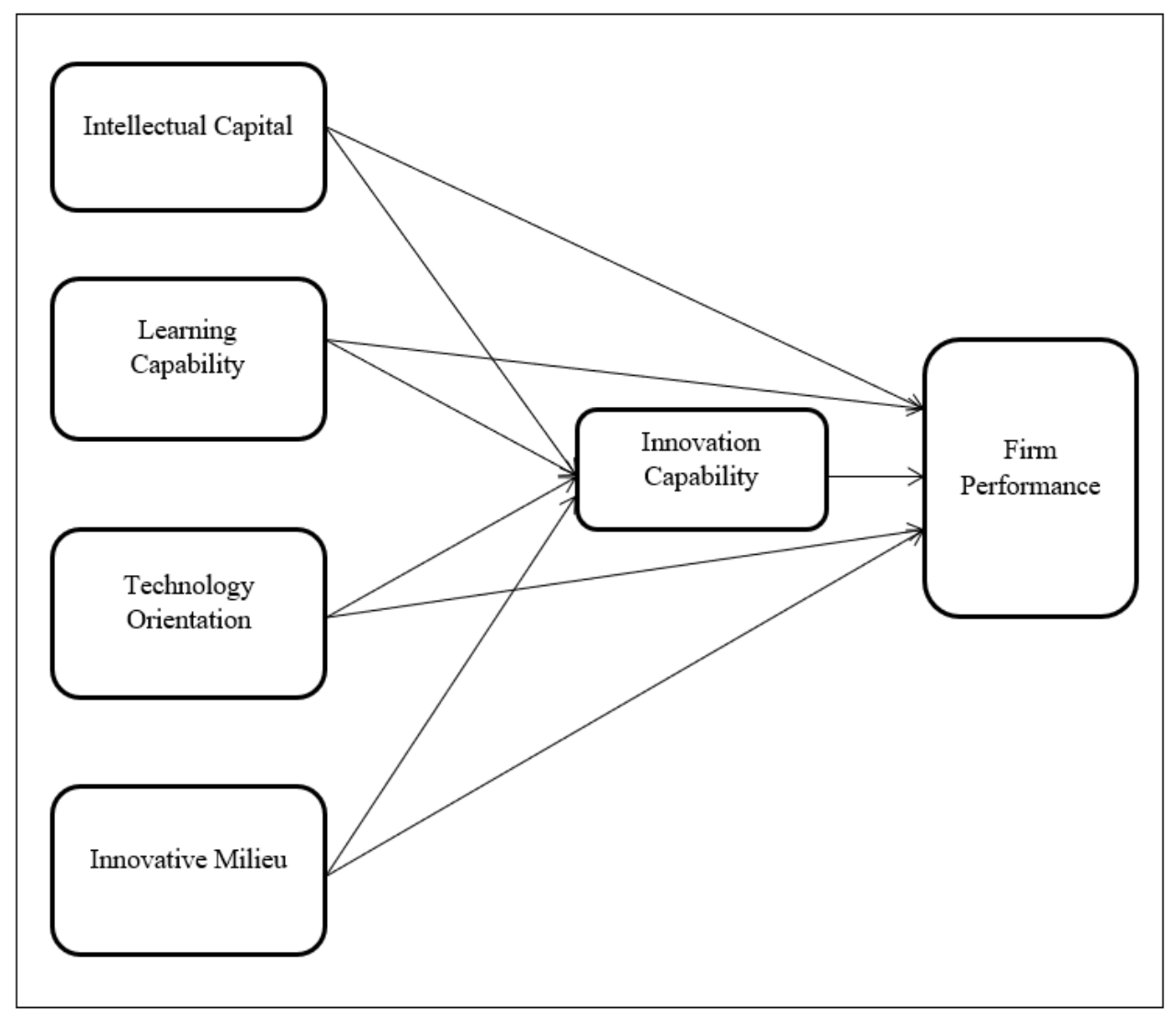




\section{Methodology}

\section{Sample}

The definition of SMEs is based on the decree of the Indonesian Ministry of Cooperatives and SMEs which was published by the Law on Small Enterprises Number 20 of 2008. The database of the Ministry of ICT indicated that there were 1,200 registered ICT service SMEs in Indonesia, and the majority of firms (i.e., 840 firms or $70 \%$ ) and innovative milieux were located in Jakarta and Bandung. Data were collected using a purposive random sampling and a directory of innovation clusters in Indonesia (Dhewanto et al., 2012, 2014) was used to find firms that meet the following criteria, (1) company which operates in the service sector, (2) company's annual revenue and asset value need to be in line with the criteria of the Ministry of SMEs, (3) company should be established for three or more years; (4) company must be located in spatial proximity and (5) company should actively develop new products and/or services.

There were 260 questionnaires usable for data analysis. Sixty-two percent of participants were founders of the business whilst thirty-eight per cent of participants were CEO Managers, indicating that all participants have knowledge and information related to firm innovation capability and performance. Thirty-three per cent of companies were established after 2009, whereas 35\% were founded between 2005 and 2009 and the rest companies (35\%) before 2005.

\section{Measurements}

In this paper, three constructs were conceptualized as second order constructs; innovation capability, intellectual capital and learning capability (Type II). Measurements of innovation capability were adopted from Hogan et al. (2011) because the scales were specifically developed and tested in a service environment. Furthermore, since dynamic capability theory underpinned the adoption of the innovation capability construct, scales used for measurement should be seen as a continuous process in developing capabilities to innovate rather than results of innovation (Forsman, 2011).

According to Hogan et al. (2011), innovation capability embraced three components; client-focused innovation capability, technology-focused innovation capability and marketing-focused innovation capability. Contrary to the original references, the measurement scales adopted in the present study do not compare the ability of a firm to innovate with its main competitors since most SMEs seem to lack knowledge of their competitors. The measurement items included client-focused innovation capability (CFIC) and these suggest the extent to which a firm can offer novel and useful solutions to clients. The CFIC is important in a service context and links three types of innovation capability dimensions (service and product, problem solutions and behavioural innovation capability) (Hogan et al., 2011). The marketing-focused innovation capability (MFIC) indicates the extent to which the company can develop 
and apply innovative marketing programs. Hogan et al. (2011) argued that firms can stay ahead of the competition when they can develop new and creative marketing programs. Additionally, key employees have generally played a major role in marketing programs (Laing \& McKee 2000). Finally, technology-focused innovation capability (TFIC) reflects the degree to which a firm has been able to develop new products with new technologies. This component is integrated into product and process innovations (Hogan et al., 2011). Firm performance was measured by the scale developed by Wiklund and Shepherd (2003) since it has been tested empirically and produced robust reliability and validity. This measure of firm performance also includes self-reported data that can be used to examine the dimensions of both financial and non-financial performance related to innovation.

The intellectual capital measurement scale was adapted from a study conducted by Subramaniam and Youndt (2005) as their work was highly cited and recognized to embrace human, social, and organizational capitals (Aramburu, Saenz \& Blanco, 2013). Furthermore, learning capability was formatively measured by accounting for the influence of its components; interaction with the external environment, experimentation, dialogue, participation in decision-making and risk-taking. It was measured by five dimensions developed by Chiva, Alegre, and Lapiedra (2007) as the scales incorporate perspectives of organizational learning and providing comprehensive scales to measure (Chiva \& Alegre, 2009). To support technological orientation, its scales were adapted from Akman and Yilmaz (2008) and Hakala and Kohtamäki (2011). Measurement items of innovative milieu were adopted from the study of Siahaan (2017) as they were developed for the service industry in a developing country.

\section{Data Analysis}

Data analysis was undertaken by using Partial Least Squares-Structural Equation Modeling (PLS-SEM). PLS-SEM is considered the most appropriate technique for investigating a model that consists of both reflective and formative measures as adopted in this study with a small-sized sample (Hair et al., 2017). Additionally, it works better than regression analysis to conduct a mediation assessment (Hair et al., 2019).

\section{Measurement Properties}

Before data analysis, an assessment of common method bias was undertaken by using Harman's single factor test. The results showed that twenty-one factors emerged with the first factor and these explained $17 \%$ of the total variance. Thus, it indicated that common method bias was not present. Furthermore, the result of a full collinearity test indicated the absence of collinearity as the Variance Inflation factor (VIF) was lower than 3.3 (Kock, 2015). In addition, data were free from outlier and normality issues. 


\section{First-Order Measurement Model}

Assessment of the outer measurement model of reflective and formative indicators was undertaken by following the guidelines adopted from Becker, Klein, and Wetzels (2012) that used the repeated indicator approach. To ensure the validity of the constructs, convergent and discriminant validity tests are undertaken (see Table 1). Table 2 displays the square root of AVE as the diagonal elements and the correlations among constructs in off-diagonal rows and columns.

Table 1: Assessment of the Measurement Model

\begin{tabular}{|c|c|c|c|}
\hline Constructs & Loadings & $\mathbf{C R}$ & AVE \\
\hline \multicolumn{4}{|l|}{ Innovation Capability (ICap): } \\
\hline Client-focused innovation cap (CFIC) & & 0.90 & 0.74 \\
\hline CFIC15 & 0.87 & & \\
\hline CFIC16 & 0.90 & & \\
\hline CFIC17 & 0.81 & & \\
\hline Marketing-focused innovation cap (MFIC) & & 0.88 & 0.71 \\
\hline MFIC20 & 0.84 & & \\
\hline MFIC21 & 0.86 & & \\
\hline MFIC22 & 0.83 & & \\
\hline Technology-focused innovation cap (TFIC) & & 0.89 & 0.72 \\
\hline TFIC24 & 0.84 & & \\
\hline TFIC25 & 0.89 & & \\
\hline TFIC26 & 0.82 & & \\
\hline \multicolumn{4}{|l|}{ Intellectual Capital: } \\
\hline Human capital (HC) & & 0.92 & 0.74 \\
\hline $\mathrm{HC} 27$ & 0.83 & & \\
\hline $\mathrm{HC} 28$ & 0.89 & & \\
\hline $\mathrm{HC} 29$ & 0.84 & & \\
\hline $\mathrm{HC} 30$ & 0.90 & & \\
\hline Social capital (SC) & & 0.88 & 0.71 \\
\hline SC32 & 0.83 & & \\
\hline SC33 & 0.89 & & \\
\hline SC34 & 0.81 & & \\
\hline Organizational capital (OC) & & 0.89 & 0.74 \\
\hline OC38 & 0.84 & & \\
\hline OC39 & 0.90 & & \\
\hline OC40 & 0.84 & & \\
\hline Dialogue (Dial) & & 0.89 & 0.73 \\
\hline Dial49 & 0.90 & & \\
\hline Dial50 & 0.89 & & \\
\hline Dial51 & 0.85 & & \\
\hline Experimentation (EXP) & & 0.90 & 0.81 \\
\hline EXP41 & 0.82 & & \\
\hline EXP42 & 0.84 & & \\
\hline Participation (PART) & & 0.90 & 0.75 \\
\hline PART52 & 0.84 & & \\
\hline
\end{tabular}




\begin{tabular}{|c|c|c|c|}
\hline PART53 & 0.89 & & \\
\hline PART54 & 0.88 & & \\
\hline Interaction (Inter) & & 0.87 & 0.68 \\
\hline Inter45 & 0.8 & & \\
\hline Inter46 & 0.85 & & \\
\hline Inter47 & 0.83 & & \\
\hline Risk-taking (RT) & & 0.92 & 0.86 \\
\hline RT43 & 0.92 & & \\
\hline RT44 & 0.93 & & \\
\hline Technology Orientation (TO) & & 0.92 & 0.66 \\
\hline TO58<- TO & 0.78 & & \\
\hline TO59<- TO & 0.80 & & \\
\hline TO60<- TO & 0.83 & & \\
\hline TO61 <- TO & 0.81 & & \\
\hline TO62<- TO & 0.82 & & \\
\hline TO63 <- TO & 0.83 & & \\
\hline Innovative Milieu (IM) & & 0.89 & 0.66 \\
\hline IM64 <- IM & 0.75 & & \\
\hline IM77 <- IM & 0.84 & & \\
\hline IM81 <- IM & 0.81 & & \\
\hline IM85 <- IM & 0.85 & & \\
\hline Firm Performance (FP) & & 0.93 & 0.69 \\
\hline FP87 <- FP & 0.83 & & \\
\hline FP88 <- FP & 0.73 & & \\
\hline FP90 <- FP & 0.82 & & \\
\hline FP92 <- FP & 0.88 & & \\
\hline FP93 <- FP & 0.88 & & \\
\hline FP94 <- FP & 0.86 & & \\
\hline
\end{tabular}

Notes: $C R^{*}=$ Composite Reliability; $A V E^{* * *}=$ Average Variance Extracted 
Table 2: Convergent and Discriminant Validity of Reflective Measures

\begin{tabular}{|c|c|c|c|c|c|c|c|c|c|c|c|c|c|c|c|c|}
\hline & & AVE & 1 & 2 & 3 & 4 & 5 & 6 & 7 & 8 & 9 & 10 & 11 & 12 & 13 & 14 \\
\hline 1 & CFIC & 0.74 & 0.86 & & & & & & & & & & & & & \\
\hline 2 & Dial & 0.73 & 0.53 & 0.85 & & & & & & & & & & & & \\
\hline 3 & EXP & 0.81 & 0.51 & 0.53 & 0.90 & & & & & & & & & & & \\
\hline 4 & FP & 0.69 & 0.50 & 0.47 & 0.46 & 0.83 & & & & & & & & & & \\
\hline 5 & $\mathrm{HC}$ & 0.74 & 0.59 & 0.58 & 0.54 & 0.44 & 0.86 & & & & & & & & & \\
\hline 6 & $\mathrm{IM}$ & 0.66 & 0.34 & 0.47 & 0.43 & 0.53 & 0.48 & 0.81 & & & & & & & & \\
\hline 7 & Inter & 0.68 & 0.59 & 0.54 & 0.49 & 0.49 & 0.57 & 0.53 & 0.82 & & & & & & & \\
\hline 8 & MFIC & 0.71 & 0.64 & 0.53 & 0.50 & 0.54 & 0.63 & 0.51 & 0.57 & 0.84 & & & & & & \\
\hline 9 & $\mathrm{OC}$ & 0.74 & 0.57 & 0.59 & 0.50 & 0.39 & 0.60 & 0.53 & 0.58 & 0.55 & 0.86 & & & & & \\
\hline 10 & PART & 0.75 & 0.49 & 0.57 & 0.53 & 0.40 & 0.65 & 0.51 & 0.55 & 0.53 & 0.62 & 0.87 & & & & \\
\hline 11 & RT & 0.86 & 0.49 & 0.44 & 0.54 & 0.39 & 0.56 & 0.43 & 0.54 & 0.50 & 0.56 & 0.48 & 0.93 & & & \\
\hline 12 & SC & 0.71 & 0.58 & 0.61 & 0.54 & 0.49 & 0.61 & 0.50 & 0.65 & 0.59 & 0.59 & 0.59 & 0.51 & 0.84 & & \\
\hline 13 & TFIC & 0.72 & 0.66 & 0.56 & 0.57 & 0.52 & 0.69 & 0.55 & 0.65 & 0.65 & 0.60 & 0.62 & 0.50 & 0.63 & 0.85 & \\
\hline 14 & TO & 0.66 & 0.65 & 0.59 & 0.52 & 0.52 & 0.71 & 0.51 & 0.60 & 0.66 & 0.65 & 0.57 & 0.62 & 0.57 & 0.65 & 0.81 \\
\hline
\end{tabular}

Notes: The square root of AVE is shown in diagonal while the correlations are off-diagonal. $H C=H u m a n$ capital, $S C=$ social capital $; O C=$ organizational capital; $M F I C=$ Marketing-focused innovation capability; TFIC = Technology-focused innovation capability; CFIC = Client-focused innovation capability; IM = Innovative milieu; INTER = Interaction with external environment, EXP = Experimentation $;$ DIAL = Dialogue, OLC=Organizational learning capability; $P A R T=$ Participation in decision-making; $R T=$ Risk-taking; $T O=$ Technological orientation

\section{Formative Second-Order Measures}

The indicator validity of the formative constructs was evaluated by testing the magnitude, sign, and significance level of its relationships to its formative indicators. The results are provided in Table 3.

Table 3: Indicator Validity of Formative Measurements

\begin{tabular}{|c|l|c|c|c|c|}
\hline Constructs & \multicolumn{1}{|c|}{ Paths } & $\begin{array}{c}\text { Path } \\
\text { Coefficient }\end{array}$ & $\begin{array}{c}\text { Standard } \\
\text { Error }\end{array}$ & $\boldsymbol{t}$-Statistics & Significant \\
\hline Innovation & CFIC -> ICap & 0.26 & 0.11 & 2.40 & Yes \\
Capability & MFIC -> ICap & 0.49 & 0.11 & 4.31 & Yes \\
& TFIC ->ICap & 0.38 & 0.12 & 3.25 & Yes \\
\hline Intellectual & HC -> IC & 0.46 & 0.08 & 5.46 & Yes \\
Capital & SC -> IC & 0.45 & 0.08 & 5.53 & Yes \\
& OC -> IC & 0.25 & 0.07 & 3.34 & Yes \\
\hline Learning & Exp -> OLC & 0.26 & 0.07 & 3.82 & Yes \\
Capability & RT -> OLC & $\mathbf{0 . 1 4}$ & $\mathbf{0 . 0 8}$ & $\mathbf{1 . 8 4}$ & No \\
& Inter -> OLC & 0.41 & 0.07 & 5.97 & Yes \\
& Dial -> OLC & 0.28 & 0.06 & 4.72 & Yes \\
& PART -> OLC & 0.17 & 0.07 & 2.23 & Yes \\
\hline
\end{tabular}

As evident in Table 3, all coefficient paths are above 0.1. However, one coefficient path has a low t-statistics value $(\mathrm{t}$-stat $=1.84)$. This implies that risk-taking has no significance in explaining learning capability. According to Hair et al. (2014), if an indicator is not significant in explaining a construct but is strongly supported by the underlying theory, the non-significant indicator should be kept in the formative measurement model. 


\section{Structural Model}

Results of a structural model assessment indicate a robust structural model with R2 value $72.90 \%$, explaining the variance of innovation capability as described by intellectual capital, learning capability, and technology orientation. In addition, the structural model also depicts $42.70 \%$ of the variance in firm performance as explained by intellectual capital, learning capability, technology orientation, and innovative milieu. Details on bootstrapping results of path coefficient, standard error and tstatistics of structural model are presented in Table 4.

Table 4: Bootstrapping Results

\begin{tabular}{|l|l|l|l|}
\hline Relationship & $\begin{array}{l}\text { Path } \\
\text { Coefficient }\end{array}$ & $\begin{array}{l}\text { Standard } \\
\text { Error }\end{array}$ & $\begin{array}{l}\boldsymbol{t} \text { - } \\
\text { Statistics }\end{array}$ \\
\hline Intellectual Capital (IC)-> Innovation Capability (ICap) & 0.36 & 0.08 & 4.32 \\
\hline Learning Capability (OLC)-> Innovation Capability (ICap) & 0.29 & 0.08 & 3.79 \\
\hline $\begin{array}{l}\text { Technology Orientation (TO)-> Innovation Capability } \\
\text { (ICap) }\end{array}$ & 0.25 & 0.06 & 3.95 \\
\hline Innovative Milieu (IM)-> Innovation Capability (ICap) & 0.05 & 0.05 & 1.09 \\
\hline Intellectual Capital (IC)-> Firm Performance (FP) & -0.14 & 0.11 & 1.28 \\
\hline Learning Capability (OLC)-> Firm Performance (FP) & 0.18 & 0.09 & 2.00 \\
\hline Technology Orientation (TO)-> Firm Performance (FP) & 0.12 & 0.07 & 1.63 \\
\hline Innovative Milieu (IM)-> Firm Performance (FP) & 0.26 & 0.06 & 4.06 \\
\hline Innovation Capability (ICap)-> Firm Performance (FP) & 0.34 & 0.09 & 3.78 \\
\hline
\end{tabular}

*significant at $\rho<0.05$ (two-tailed); t-statistics $>1.96$

Figure 3 which shows the results of bootstrapping, suggests that intellectual capital, learning capability, and technology orientation significantly influence the variance in innovation capability. All three constructs have the same positive sign, reflecting relationships indicated in the underlying theory and demonstrate similar magnitude in their path coefficients $(\beta=0.36, \beta=0.29$, and $\beta=0.25$ respectively with $\rho<0.05)$ except for innovative milieu $(\beta=0.05, \rho>0.05)$. Furthermore, innovative milieu is not significant in explaining variance in innovation capability. Likewise, intellectual capital $(\beta=-0.14, t=1.28, \rho>0.05)$ and technology orientation $(\beta=0.12, t=1.63$, $\rho>0.05$ ) are not significant with reference to firm performance. Results of the effect size assessment are provided in Table 5. 
Figure 3: Bootstrapping for Structural Model

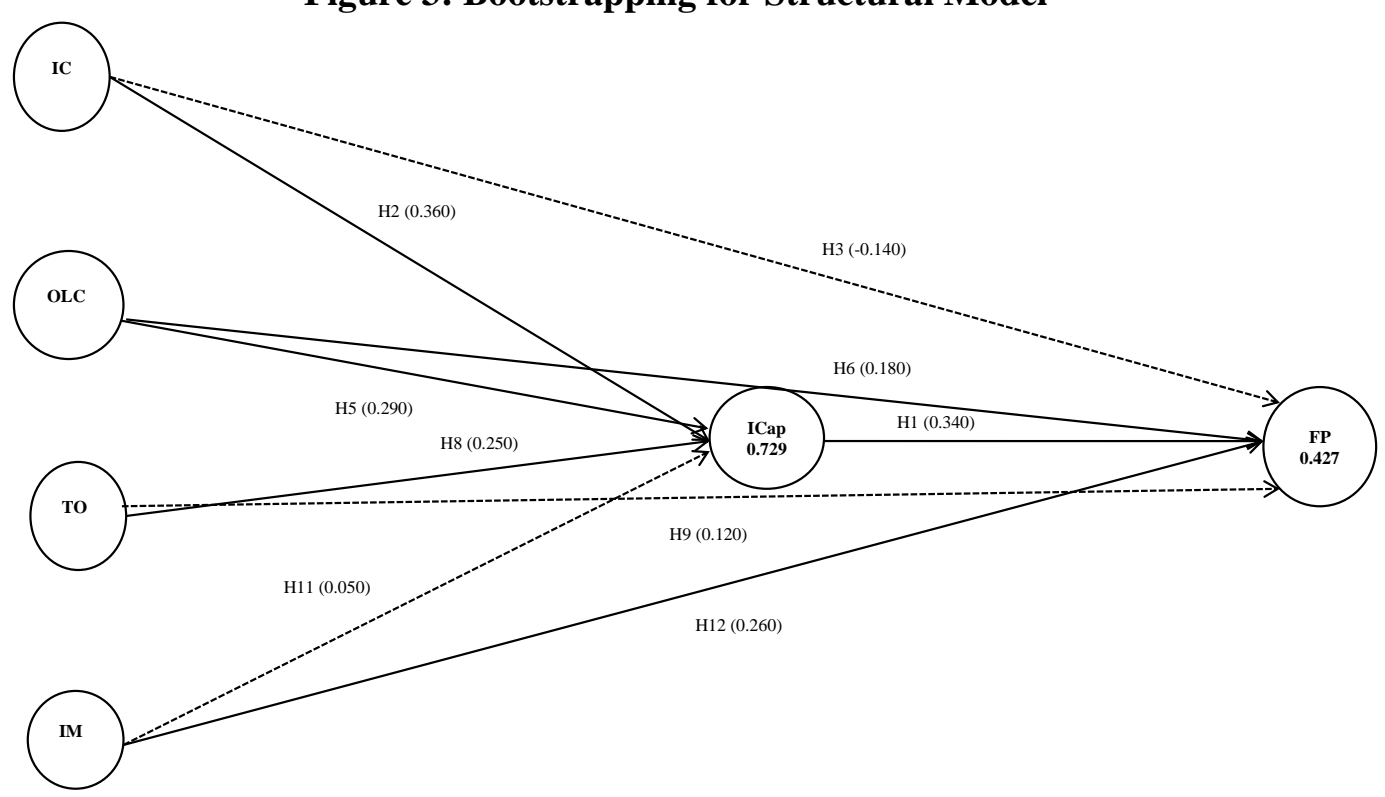

Note: $I C=$ Intellectual Capital $;$ OLC $=$ Learning Capability; $T O=$ Technology Orientation $; I M=$ Innovative Milieu; ICap $=$ Innovation Capability; $F P=$ Firm Performance; - - - . - . = nonsignificant relationship; ------ = significant relationship

Table 5: Summary of Effect Size $\left(\mathbf{f}^{2}\right)$

\begin{tabular}{|c|c|c|c|c|c|c|}
\hline \multirow[t]{2}{*}{ Constructs } & \multicolumn{3}{|c|}{ Innovation capability } & \multicolumn{3}{|c|}{ Firm performance } \\
\hline & $\boldsymbol{\beta}$ & $\mathbf{R}^{2}$ excluded & $\mathbf{f}^{2}$ & $\boldsymbol{\beta}$ & $\mathbf{R}^{2}$ excluded & $\mathbf{f}^{2}$ \\
\hline Innovation & & & & 0.34 & 0.40 & 0.04 \\
\hline $\begin{array}{l}\text { Intellectual } \\
\text { Capital }\end{array}$ & 0.36 & 0.70 & 0.11 & -0.14 & 0.42 & 0.01 \\
\hline $\begin{array}{l}\text { Learning } \\
\text { capability }\end{array}$ & 0.29 & 0.71 & 0.08 & 0.18 & 0.42 & 0.01 \\
\hline $\begin{array}{l}\text { Technology } \\
\text { orientation }\end{array}$ & 0.25 & 0.71 & 0.08 & 0.12 & 0.42 & 0.01 \\
\hline $\begin{array}{l}\text { Innovative } \\
\text { milieu }\end{array}$ & 0.05 & 0.73 & 0.03 & 0.26 & 0.39 & 0.07 \\
\hline
\end{tabular}

In addition, the predictability of the structural model can be examined in more detail by calculating the value of a non-parametric Stone-Geisser test or Q2. This test employs a blindfolding procedure (Henseler, Ringle \& Sinkovics, 2009) to generate residual variances. In this present study, firm performance is the only endogenous variable that meets the criteria. The result showed a value of 0.49 , which is greater than 0 , which confirms that the structural model has an appropriate predictive significance with firm performance as the final endogenous construct. 


\section{Mediation Analysis}

The mediation analysis adopted the guidelines from Zhao, Lynch, and Chen (2010) which was recommended by Memon et al. (2018), and Rungtusanatham et al. (2014). The findings show that that innovation capability mediates the impact of intellectual capital on firm performance, supporting $\mathrm{H} 4(\beta=0.12, \mathrm{t}=2.86, \rho<0.05)$. This implies that innovation capability mediates the relationship between intellectual capital and firm performance (Aramburu, Saenz \& Blanco, 2015; Lee, Yang \& Huang, 2019).

Furthermore, the result of the mediation assessment reveals that innovation capability mediates the impact of learning capability on firm performance $(\beta=0.10, t=2.80$, $\rho<0.05$ ) (Gomez \& Wojahn, 2017; Sawean \& Ali, 2020). Similarly, the statistical results showed that technology orientation indirectly impacts firm performance through innovation capability. Technological advances and breakthroughs create value for enterprises when firms acknowledge the right opportunities to commercialize. In the ICT industry, where technologies become easily obsolete and are rapidly replaced, introducing novel technology triggers imitators to shorten the period when innovators can benefit from the advantage of being a technology leader (Tseng, Chang, \& Chen, 2019). Statistical results on the mediation analysis are provided in Table 6.

Table 6: Mediation Effect

\begin{tabular}{lllll}
\hline Path & $\begin{array}{l}\text { Indirect } \\
\text { Effect } \\
(\mathbf{a} \mathbf{x} \text { b) }\end{array}$ & $\mathbf{S e}^{\mathbf{a}}$ & $\begin{array}{l}\text { T-Stat } \\
(\mathbf{a x b}) / \mathbf{S T D}\end{array}$ & $\boldsymbol{\Sigma E f f e c t ~}^{\mathbf{b}}$ \\
\hline $\mathrm{IC} \rightarrow$ FP & $0.12^{*}$ & 0.04 & 2.86 & 0.26 \\
$\mathrm{LC} \rightarrow$ FP & $0.10^{*}$ & 0.04 & 2.80 & 0.28 \\
$\mathrm{TO} \rightarrow$ FP & $0.08^{*}$ & 0.03 & 2.65 & 0.20 \\
$\mathrm{IM} \rightarrow$ FP & $0.02^{*}$ & 0.02 & 1.04 & n.s ${ }^{* *}$ \\
\hline
\end{tabular}

a: Standard error indirect effects

b: Total effect was calculated by summing the direct and indirect path coefficients

*: Significant at $t$-statistics 1.96, and $\rho<0.05$ (two-tailed)

**: not significant

Finally, the bootstrapping results showed the absence of innovation capability's mediating effect in explaining the relationship between innovative milieu and firm performance $(\beta=0.02, \mathrm{t}=1.04, \rho>0.05)$. The explanation for this finding is that innovative milieu has a non-significant impact on innovation capability (see discussion section) due to several shortcomings present in a milieu in Indonesia. 


\section{Discussion}

The findings of this study confirm that innovation capability is the major component and mediator that has a significant impact on the performance of Indonesian ICT SMEs. All constructs adopted in the study have small to medium effects in explaining the extent to which they influence innovation capability and firm performance. In other words, although firms may possess various combinations of intellectual capital, learning capability, technology orientation, and innovative milieu, without the presence of innovation capability, firm performance will be compromised.

Consistent with Hypothesis 1, the findings show a significant relationship between innovation capability and firm performance, suggesting that firms with innovation capability will perform better. Despite showing a small to medium effect, the role of innovation capability in explaining firm performance is significant. Innovation capability allows organizations to adapt to competition, the market and the environment (Rajapathirana \& Hui, 2018). Its significance for Indonesian ICT firms' performance is because it attempts to provide clients with unique services, implement novel ways to market their services and launch new software on the market (e.g., using up-to-date marketing tactics such as social media). As technologies and services (e.g., software, hardware, maintenance service and technology) in the ICT industry become obsolete quickly, firms are forced to keep updating their offerings to stay competitive in the market by developing and enhancing firm innovation capability.

Research shows that intellectual capital has a significant impact on firm innovation capability with a medium effect size, supporting $\mathrm{H} 2$. The significance of intellectual capital to explain innovation capability is consistent with previous research (Aramburu, Saenz \& Blanco, 2015). To innovate, these companies require knowledge that is derived from their intellectual capital assets. Knowledge obtained from their employees, networks and embedded within organizational structure or culture can be used to advance their marketing programs, technological skills and client-focused strategies that may improve their products and services compared to those of their competitors. Thus, innovation capability essentially acts as a transformer shaping discrete organizational assets into a far more powerful current that enables firms to better deal with hyper-competition, uncertainty and ambiguity and in the ICT sector, shortened and at times volatile product and service life cycles.

Surprisingly, intellectual capital had no direct impact on firm performance, indicating that H3 is not supported. One possible explanation for its non-significance is that creative and innovative workers, networks and organizational structures and cultures supporting innovation do not automatically improve firm performance. This remains true unless firms can integrate and transform these strategic advantages into capabilities that are rare, unique, and difficult-to-imitate (e.g., innovation capability). 
Furthermore, although learning capability shows a small effect size, it wields a significant impact on firm innovation capability, indicating that H5 is supported (Sheng \& Chien, 2016). In this industry, firms can develop state-of-the-art technology when they possess learning capability (Altinay et al., 2016). The ability of firms to collect, process and transform information and knowledge internally and externally is essential for innovations. In addition, the results show that H6 was supported which suggested that learning capability significantly influences firm performance. Firms with learning capability are more adaptive and alert to customers' demands. As a result, SMEs can offer superior new products and services more efficiently than their rivals. Therefore, they quickly respond to the market challenges by providing superior products or services and enhance their firm's performance through increased profits, market share and service success (Altinay et al., 2016).

The results showed that hypothesis 8 was supported (Zhou, Yim \& Tse, 2005) with a small effect size. The existing literature on technology orientation suggested that firms with a technology orientation possess superior technological skills and can apply them to the marketing of innovative products (Mu et al., 2017). In addition, technology is the key driver of innovation in the ICT sector (Zhou, Yim \& Tse, 2005). Unexpectedly, findings showed insignificant relationships between technology orientation and firm performance. These contradict those of previous studies on technology orientation (Hakala \& Kohtamäki, 2011; Sainio, Ritala \& HurmelinnaLaukkanen, 2012) because it may not be an effective approach in driving superior firm performance. The mediating effects of innovation capability appear to be important for firms in the sector to achieve better business performance.

Contrary to Hypothesis 11, the findings revealed that innovative milieu does not significantly influence innovation capability. This finding is counter to earlier work that acknowledged the important role of milieu in fostering firm innovation capability (e.g., Camagni \& Capello, 2017; Gilbert, 2007). The non-significance of innovative milieu in explaining innovation capability in the Indonesian context has several reasons (Dhewanto et al., 2012, 2014): (1) Collaborations between academia, SMEs and government agencies are still weak and rather nascent in nature. (2) The ICT milieux in Indonesia have not been anchored with 'lighthouse enterprises' that have the experience, capability and global presence to both perform at a high level and to teach, enable and collaborate with Indonesian ICT SMEs in building collective capacity around innovation capability. (3) Resources appear to be unequally distributed in the milieux studied, and there was evidence relating to e.g., rent-seeking activities of firms that directly impact on collective capacity of firms in milieu to foster innovation capability. (4) Poor linkages to the markets where SMEs can commercialize their services.

Consistent with previous research (Kulkalis, 2010), empirical results showed that innovative milieu significantly influences firm performance with a small effect size. By co-locating in a defined region, Indonesian ICT SMEs can better cope with their problems in regard to resources, information and skills and benefit from the facilities and resources (e.g., workforce) available in the location. Most activities and business 
collaborations present in the ICT milieux such as the reduction of production costs, access to skilled labour, and the improvement of capital and physically productive resources are necessary for businesses to increase their sales and revenues.

\section{Conclusion, Limitations and Future Research Directions}

In this study, innovation capability has a decisive influence on firm performance. Assessing and understanding antecedents that influence innovation capability and business performance are crucial not only for large enterprises but as this study has highlighted for SMEs, particularly in the ICT sector in Indonesia. Investment in the development of intellectual capital, learning capability and technology orientation enable better leveraging of firm innovation capability, while improving both the firmbased and region-based management of firms in a milieu may lead to better firm performance. The results of this research provide clear indications of a possible path that should be considered in efforts to build valuable innovation capability that can drive better firm performance from the engine room of most nations' economies, whether advanced or developing, its SMEs.

This study has three main limitations. First, the framework is developed in an Indonesian context. Consequently, the results of this research do not apply to other countries. Generalizing and applying the outcomes in other contexts without taking into account the functioning of other countries and environments can lead to unreliable results. Therefore, future research should test for the conceptual framework developed in this study. Testing the model in other countries may lead to the need to re-evaluate the non-significant factors mentioned.

Second, the data collection method uses a cross-sectional design. This means that perceptions regarding intellectual capital, learning capability, technology orientation and innovation milieu in explaining firm innovation capability and performance are collected at a single point in time. A study using mixed methods could potentially discover the underlying reasons as to how the independent variables influence innovation capability and firm performance. Finally, building on the conceptual model of the antecedents of innovation capability and firm performance of Indonesian ICT SMEs, a study on the innovation capability index of these SMEs could be potentially developed based on the findings of this study. An index of innovation capability could measure the extent to which firms have the potential to develop innovative capabilities. Firm owners/founders and managers, could therefore, direct their resources, energy and capabilities to factors that most significantly influence the development of innovation capability and improvement of firm performance. 


\section{Practical Implications for Asian Business}

The main practical implication of this research for SME owners and managers is that innovation capability is the key driver of superior business performance. Although ICT SMEs have intellectual capital, organizational learning capability, technological advances or be positioned in a milieu, their firm performance may not improve without the presence of innovation capability. As the sector has grown considerably over the past year, ease of use has become one of the most crucial requirements for producing attractive, useful and desirable software or services. Consequently, owners and managers should be aware that creative and innovative ideas arise when they understand what customers want and why they want it. Thus, training and empowering employees to be more creative in delivering meaningful experiences for clients are crucial.

The findings of this study have managerial implications for policy-makers. These impacts help improve the innovation capability and firm performance of Indonesian ICT SMEs based on the factors examined. First, the primary source of innovation capability and firm performance is the quality of human capital in a nation. With regards to this, Indonesia lacks skilled ICT professionals. Therefore, the Indonesian Government needs to develop a larger pool of qualified ICT professionals for ICT firms to better innovate. The creation of a skilled workforce needs to start with early schooling and extend to the higher education system.

Second, unexpectedly, being spatially close in a milieu does not promote the innovation capability of Indonesian ICT SMEs. To catalyse the potential of SMEs better in a milieu, there would be some merit to the concept of potentially anchoring the milieu with multinational corporations that operate in various industries or sectors of the economy. For example, the government could offer tax credits or relief to such multinational corporations and grant research funding for research institutes and universities when they are involved in nurturing an ICT milieu in a specific region. Finally, a milieu requires diverse sectors and actors to work since this diversity drives innovation. The knowledge obtained from different types of corporations may provide SMEs with the impetus to foster greater firm innovation capability and so develop sustainable competitive advantage. Being located in a milieu with diverse interconnected firms and specialized suppliers may provide SMEs with further productivity and cost advantages. Therefore, a milieu manager needs to take into account the industrial diversity that allows localized collaboration to select tenants.

Theoretically, this study offers three implications; first, the most puissant contribution of this study to the innovation literature is perhaps due to the nature of this research which integrates firms' resources, capabilities and inter-firm interactions in spatial proximity to enable a more nuanced understanding of firm innovation capability and performance. Previous work in this domain predominantly focused on how organizational resources and capabilities impact on innovation capability and firm performance. As a result, the constructs adopted in earlier work were more firmcentric, but neglected the role of businesses' interactions between them and with other 
organizations (Fitjar, Gjelsvik \& Rodriguez-Pose, 2013; Piazza et al., 2019). This objective is particularly important given the strategy of clustering of ICT SMEs in milieux in Indonesia.

Second, the non-significance of innovative milieu in explaining firm innovation capability contradicts what has been postulated concerning proximity and its agglomerated benefits in advanced countries (Aydalot \& Keeble, 2018; Keeble, 2017). The existing literature on innovative milieu suggests that firms can enhance their innovation capability when they are geographically close. However, as a case in point, the Indonesian ICT milieu still needs to be further improved due to various issues previously discussed which will limit its effectiveness.

Finally, technological orientation was found to have a non-significant impact on firm performance, thus questioning the generalizability of results from countries with more advanced infrastructure, markets, and practices (Hakala \& Kohtamäki, 2011). The findings revealed that the relationship between technology orientation and firm performance is mediated by innovation capability and this has implications for theory development when investigating the firm performance of ICT companies in developing economies.

\section{References}

Akman, G., \& Yilmaz, C., (2008), "Innovative capability, innovation strategy and market orientation: An Empirical analysis in Turkish software industry", International Journal of Innovation Management, vol. 12, no. 1, pp. 69-111.

Alegre, J., \& Chiva, R., (2008), "Assessing the impact of organizational learning capability on product innovation performance: An empirical test", Technovation, vol. 28, no. 6, pp. 315-326.

Al-Kalouti,J., Kumar, V., Kumar, N., Garza-Reyes, J. A., Upadhyay, A., \& Zweigelaar, J. B., (2020), "Investigating innovation capability and firm performance in service firm", Strategic Change, vol. 29, no. 1, pp. 103-113.

Altinay, L., Madanoglu, M., De Vita, G., Arasli, H., \& Ekinci, Y., (2016), "The interface between organisational learning capability, entrepreneurial orientation, and SME growth", Journal of Small Business Management, vol. 54, no. 3, pp. 871-891.

Aramburu, N., Sáenz, J., \& Blanco, C., (2013), "Structural capital, innovation capability, and company performance in technology-based Colombian firms", Proceedings of the International Conference on Intellectual Capital, Knowledge, Management \& Organizational Learning, pp. 39-60.

Aramburu, N., Sáenz, J., \& Blanco, C., (2015), "Structural capital, innovation capability, and company performance in technology-based Colombian firms", Proceedings of the Cuardenos de Gestion, vol. 15, no. 1, pp. 20-29.

Asheim, B. T., Grillitsch, M., \& Trippl, M., (2016), "Regional innovation systems: Pastpresent-future", In Handbook on the geographies of innovation, Edward Elgar Publishing, London.

Aydalot, P., \& Keeble, D., (2018), High-technology industry and innovative environments in Europe: An overview, Routledge, London.

Barczak, G., (1994), "Gaining superior performance of new products in the telecom", The Journal of Business \& Industrial Marketing, vol. 9, no. 4, pp. 19-32.

Barney, J., (1991), "Firm resources and sustained competitive advantage", Journal of Management, vol. 17, no. 1, pp. 99-120. 
Becker, J. M., Klein, K., \& Wetzels, M., (2012), "Hierarchical latent variable models in PLSSEM: Guidelines for using reflective-formative type models", Long Range Planning, vol. 45, no. 5-6, pp. 359-394.

Belussi, F., \& Hervas-Oliver, J. L., (2018), Agglomeration and firm performance, Springer, Berlin.

Bittencourt, B. A., Galuk, M. B., Daniel, V. M., \& Zen, A. C., (2019), "Cluster innovation capability: A systematic review", International Journal of Innovation, vol. 7, no. 1, pp. 26-44.

Camagni, R. P., (1995), "The concept of innovative milieu and its relevance for public policies in European lagging regions", Papers in Regional Science, vol. 74, no.4, pp. 317-340.

Camagni, R., \& Capello, R., (2017), "The role of inter-SME, networking, and links, in innovative high-technology milieux", High-Technology Clusters, Networking, and Collective Learning, pp. 118-155.

Camps, J., Oltra, V., Aldás-Manzano, J., Buenaventura-Vera, G., \& Torres-Carballo, F., (2016), "Individual performance in turbulent environments: The role of organizational learning capability and employee flexibility", Human Resource Management, vol. 55, no.3, pp. 363-383.

Carmona-Lavado, A., Cuevas-Rodríguez, G., \& Cabello-Medina, C., (2013), "Service innovativeness and innovation success in technology-based knowledge-intensive business services: An intellectual capital", Industry and Innovation, vol. 20, no. 5, pp. 133-156.

Cenfettli, R. T., \& Bassellier, G., (2009), "Interpretation of formative measurement in information system research", MIS Quarterly, vol. 33, no. 4, pp. 689-708.

Chiva, R., Alegre, J., \& Lapiedra, R., (2007), "Measuring organizational learning capability among the workforce", International Journal of Manpower, vol. 28, no. 3/4, pp. 224242.

Chiva, R., \& Alegre, J., (2009), "organizational learning capability and job satisfaction: An empirical assessment in the ceramic tile industry", British Journal of Management, vol. 20, no. 3, pp. 323-340.

Dhewanto, W., Prasetio, E. A., Ratnaningtyas, S., Herliana, S., Chaeruddin, R., Aina, Q., Bayuningrat, R., \& Rachmawaty, E., (2012), "Moderating effect of cluster on firm's innovation capability and business performance: A conceptual framework", Prodia Social and Behavioural Science, vol. 65, pp. 867-872.

Dhewanto, W., Hardjakaprabon, B., Lantu, D. C., CH-Rachmawati, E., Chaerudin, R., Qorri, A., \& Herliana, S., (2014), "Triple helix model in Indonesian ICT cluster development", World Applied Sciences Journal, vol. 30, pp. 302-307.

Doloreux, D., De La Puerta, J. G., Pastor-Lopez, I., Gomez, I. P., Sanz, B., \& ZabalaIturriagagoitia, J. M., (2019), "Territorial models: To Be or not to be, that's the question", Scientometrics, vol. 120, no. 3, pp. 1163-1191.

Eisenhardt, K. M., \& Martin, J. A., (2000), "Dynamic capabilities: What are they", Strategic Management Journal, vol. 21, pp. 1105-1121.

Ferras-Hernandez, X., \& Nylund, P. A., (2019), "Clusters as innovation engines: The accelerating strengths of proximity", European Management Review, vol. 16, no. 1, pp. $37-53$

Fitjar, R. D., Gjelsvik, M., \& Rodriguez-Pose, A., (2013), "The combined impact of managerial and relational capabilities on innovation in firms", Entrepreneurship \& Regional Development, vol. 25, no. 5-6, pp. 500-520.

Forsman, H., (2011), "Structural capital, innovation capability, and size effect: An empirical study", Research Policy, vol. 40, no. 5, pp. 739-750.

Gatignon, H., \& Xuereb, J. M., (1997), "Strategic orientation of the new firm and new product performance", Journal of Marketing Research, vol. 34, no. 1, pp. 77-90.

Gilbert, D., (2007), "Firm innovativeness in SME: Lessons from Japan, international", Journal of Organizational Behaviour, vol. 12, no. 1, pp. 126-143. 
Global Innovation Index Report, (2019), Retrieved from https://www.wipo.int/edocs/pubdo cs/en/wipo_pub_gii_2019.pdf.

Gomes, G., \& Wojahn, R. M., (2017), "Organizational learning capability, innovation and performance: Study in Small and Medium-sized Enterprises (SMES)", Revista de Administração (São Paulo), vol. 52, no. 2, pp.163-175.

Guinot, J., Chiva, R., \& Mallen, F., (2016), "Linking altruism and organizational learning capability: A study from excellent human resources management organizations in Spain”, Journal of Business Ethics, vol. 138, no. 2, pp. 349-364.

Guinot, J., Miralles, S., Rodriguez-Sanchez, A., \& Chiva, R., (2020), "Do compassionate firms outperform? The role of organizational learning, Employee Relations, vol. 42, no. 3, pp. 717-734.

Hair, J. F., Hult, G. T. M., Ringle, C. M., \& Sarstedt, M., (2017), A primer on Partial Least Squares Structural Equation Modeling (PLS-SEM), Sage Publications, Thousand Oaks.

Hair, J. F., Sarstedt, M., \& Ringle, C. M., (2019), "Rethinking some of the rethinking of Partial Least Squares", European Journal of Marketing, vol. 53, no. 4, pp. 566-584.

Hakala, H., (2011), "Strategic orientations in management literature: Three approaches to understanding the interaction between market, technology, entrepreneurial and learning orientations", International Journal of Management Reviews, vol. 13, no. 2, pp. 199217.

Hakala, H., \& Kohtamäki, M., (2011), "Configurations of entrepreneurial-customer-and technology orientation: Differences in learning and performance of software companies", International Journal of Entrepreneurial Behaviour \& Research, vol. 17, no. 1, pp. 64-81.

Henseler, J., Ringle, C. M., \& Sinkovics, R. R., (2009), The use of Partial Least Squares path modeling in international marketing, Emerald Group Publishing Limited, United Kingdom.

Hogan, S. J., Soutar, G. N., McColl-Kennedy, J. R., \& Sweeney, J. C., (2011), "Reconceptualizing professional service firm innovation capability: Scale development", Industrial Marketing Management, vol. 40, no. 8, pp.1264-1273.

Hortinha, P., Lages, C., \& Lages, F., (2011), "The trade-off between customer and technology orientations: Impact on innovation capabilities and export performance", Journal of International Marketing, vol. 19, no. 3, pp. 36-58.

Inkinen, H., (2015), "Review of empirical research on intellectual capital and firm performance", Journal of Intellectual Capital, vol. 16, no. 3, pp. 518-565.

Jerez-Gómez, P., Céspedes-Lorente, J. \& Pérez-Valls, M., (2019), "Do high-performance human resource practices work? The mediating role of organizational learning capability", Journal of Management \& Organization, vol. 25, no. 2, pp.189-210.

Jiménez-Jiménez, D., \& Cegarra-Navarro, J. G., (2007), "The performance effect of organizational learning and market orientation", Industrial Marketing Management, vol. 36, no. 6, pp. 694-708.

Keeble, D., (2017), Collective learning processes in European high technology milieu, Routledge, London.

Kock, N., (2015), "Common method bias in PLS-SEM: A full collinearity assessment approach", International Journal of e-Collaboration, vol. 11, no. 4, pp. 1-10.

Kulkalis, S., (2010), "Agglomeration economies and firm performance: The case of industry clusters", Journal of Management, vol. 36, no. 2, pp. 453-481.

Lee, Y. C., Yang, Y. H., \& Huang, W. T., (2019), "The discussion on mediation of innovation capital toward human capital and performance", Archives of Business Research, vol. 7, no. 9, pp. 255-267.

Liu, Y., Diwei L. V., Ying Y., Felix, A., \& Jiang, W., (2018), “Improvisation for innovation: The contingent role of resource and structural factors in explaining innovation capability", Technovation, vol. 74-75, pp. 32-41.

Liu, X., Huang, Q., Dou, J., \& Zhao, X., (2017), "The impact of informal social interaction on innovation capability in the context of buyer-supplier dyads", Journal of Business Research, vol. 78, pp. 314-322. 
Lundvall, B. Ä., (2016), The learning economy and the economics of hope, Anthem Press, New York.

Malmberg, A., \& Maskell, P., (2002), "The elusive concept of localization economies: Towards a knowledge-based theory of spatial clustering", Environment and Planning $A$, vol. 34, no. 3, pp. 429-449.

Marshall, A., (1925), Principles of economics, Macmillan, London.

Martínez-Román, J. A., Tamayo, J. A., \& Gamero, J., (2017), "Innovativeness and its influence on growth and market extension in construction firms in the Andalusian region", Journal of Engineering and Technology Management, vol. 43, pp. 19-33.

Memon, M. A., Cheah, J. H., Ramayah, T., Ting, H., \& Chuah, F., (2018), "Mediation analysis issues and recommendations", Journal of Applied Structural Equation Modeling, vol. 2, no. 1, pp. 1-9.

Mu, J., Thomas, E., Peng, G., \& Di Benedetto, A., (2017), "Strategic orientation and new product development performance: The role of networking capability and networking ability", Industrial Marketing Management, vol. 62, pp. 187-201.

Nahapiet, J., \& Ghoshal, S., (1998), "Social capital, intellectual capital, and the organizational advantage", Academy of Management Review, vol. 23, no. 2, pp. 242-266.

OECD Science, Technology and Innovation (2019), "Science, technology, and innovation outlook", Retrieved from https://www.oecd.org/sti/oecd-science-technology-andinnovation-outlook-25186167.htm

Piazza, M., Mazzola, E., Abbate, L., \& Perrone, G., (2019), "Network position and innovation capability in the regional innovation network", European Planning Studies, vol. 27, no. 9, pp. 1857-1878.

Poudel, K. P., Carter, R., \& Lonial, S., (2019), "The impact of entrepreneurial orientation, technological capability, and consumer attitude on firm performance: A multi-theory perspective", Journal of Small Business Management, vol. 57, no. 2, pp. 268-295.

Rajapathirana, R. J., \& Hui, Y., (2018), "Relationship between innovation capability, innovation type, and firm performance", Journal of Innovation \& Knowledge, vol. 3, no. 1, pp. 44-55.

Rasiah, R., Shahrivar, R. B., \& Yap, X. S., (2016), "Institutional support, innovation capabilities, and exports: Evidence from the semiconductor industry in Taiwan", Technological Forecasting and Social Change, vol. 109, pp. 69-75.

Republic of Indonesia, (2011), Masterplan: Acceleration and expansion of Indonesia economic development 2011-2025, published by Coordinating Ministry for Economic Affairs, Jakarta.

Ritter, T., \& Gemünden, H. G., (2004), "The impact of a company's business strategy on its technological competence, network competence and innovation success", Journal of Business Research, vol. 57, no. 5, pp. 548-556.

Rungtusanatham, M., Miller, J. W., \& Boyer, K. K., (2014), "Theorizing, testing, and concluding for mediation in SCM research: Tutorial procedural recommendations", Journal of Operations Management, vol. 32, no. 3, pp. 99-113.

Salojärvi, H., Ritala, P., Sainio, L. M., \& Saarenketo, S., (2015), "Synergistic effect of technology and customer relationship orientations: Consequences for market performance", Journal of Business \& Industrial Marketing, vol. 30, no. 5, pp. 511-520.

Sainio, L. M., Ritala, P., \& Hurmelinna-Laukkanen, P., (2012), "Constituents of radical innovation: Exploring the role of strategic orientations and market uncertainty", Technovation, vol. 32, no. 11, pp. 591-599.

Sawaean, F., \& Ali, K., (2020), "the impact of entrepreneurial leadership and learning orientation on organizational performance of SMEs: The mediating role of innovation capacity", Management Science Letters, vol. 10, no. 2, pp. 369-380.

Sheng, M. L., \& Chien, I., (2016), "Rethinking organizational learning orientation on radical and incremental innovation in high-tech firms", Journal of Business Research, vol. 69, no. 6, pp. 2302-2308.

Shih, K. H., Chang, C. J., \& Lin, B., (2010), “Assessing knowledge creation and intellectual capital in banking industry", Journal of Intellectual Capital, vol. 11 no. 1, pp. 74-89. 
Siahaan, D., (2017), "An empirical analysis of firm innovation capability and performance of Indonesian ICT SMEs", PhD Thesis, Royal Melbourne Institute of Technology University, Melbourne.

Sivalogathasan, V., (2016), "How to improve innovation capability? The role of intellectual capital and organizational motivation of manufacturing firms in Sri Lanka", Journal of Business Studies, vol. 32, no. 2, pp. 1-14.

Subramaniam, M., \& Youndt, M. A., (2005), "The influence of intellectual capital on the types of innovative capabilities", Academy of Management Journal, vol. 48, no. 3, pp. 450-463.

Teece, D. J., (2007), "Explicating dynamic capabilities: The nature and micro foundations of (sustainable) enterprise performance", Strategic Management Journal, vol. 28, no. 13, pp. 1319-1350.

Tseng, C. H., Chang, K. H., \& Chen, H. W., (2019), "Strategic orientation, environmental innovation capability, and environmental sustainability performance: The case of Taiwanese suppliers", Sustainability, vol. 11, no. 4, pp. 1-19.

Weerawardena, J., Mort, G. S., Salunke, S., Knight, G., \& Liesch, P. W., (2015), "the role of the market sub-system and the socio technical sub-system in innovation and firm performance: A dynamic capabilities approach", Journal of the Academy of Marketing Science, vol. 43, no. 2, pp. 221-239.

Wiklund, J., \& Shepherd, D., (2003), "Knowledge-based resources, entrepreneurial orientation, and the performance of small and medium-sized businesses", Strategic Management Journal, vol. 24, no. 13, pp. 1307-1314.

World Bank Report, (2018), "Indicators", Retrieved from https://data.worldbank.org/indic ator/

Yeşil, S., \& Doğan, I. F., (2019), "Exploring the relationship between social capital, innovation capability, and innovation", Innovation, vol. 21, no. 4, pp. 506-532.

Youndt, M. A., Subramaniam, M., \& Snell, S. A., (2004), "Intellectual capital profiles: An examination of investments and returns", Journal of Management Studies, vol. 41, no. 2, pp. 335-361.

Zafar, A., \& Mustafa, S., (2017), "SMEs and its role in economic and socio-economic development of Pakistan", International Journal of Academic Research in Accounting, Finance and Management Sciences, vol. 6, no. 4, pp. 1-16.

Zhao, X., Lynch Jr, J. G., \& Chen, Q., (2010), "Reconsidering Baron and Kenny: Myths and truths about mediation analysis", Journal of Consumer Research, vol. 37, no. 2, pp. 197-206.

Zhou, K. Z., Yim, C. K., \& Tse, D. K., (2005), "The effects of strategic orientations on technology-and market-based breakthrough innovations", Journal of Marketing, vol. 69 , no. 2 , pp. $42-60$. 


\section{Appendix}

\section{Measurement Items}

\begin{tabular}{|ll|}
\hline \multicolumn{2}{|l|}{ Innovation Capability } \\
\hline Client-Focused Innovation Capability \\
\hline CFIC 15 & $\begin{array}{l}\text { Our firm provides our clients with services/products that offer unique benefits } \\
\text { superior to those of our competitors }\end{array}$ \\
\hline CFIC 16 & Our firm solves client's problems in very innovative ways \\
\hline CFIC 17 & Our firm provides innovative ideas to clients \\
\hline CFIC 18 & Our firm presents innovative solutions to our clients \\
\hline CFIC 19 & Our firm seeks out novel ways to tackle problems \\
\hline & \\
\hline Marketing-Focused Innovation Capability \\
\hline MFIC 20 & $\begin{array}{l}\text { Our firm develops "revolutionary for the industry" marketing programs for our } \\
\text { services/products }\end{array}$ \\
\hline MFIC 21 & Our firm adopts novel ways to market our firm \\
\hline MFIC 22 & Our firm innovates with our marketing programs to keep ahead of the market \\
\hline \multicolumn{2}{|c|}{} \\
\hline Technology-Focused Innovation Capability \\
\hline TFIC 23 & Our firm innovates with new software \\
\hline TFIC 24 & Our firm innovates with new technology \\
\hline TFIC 25 & Our firm introduces new integrated systems and technology \\
\hline TFIC 26 & Our firm adopts the latest technology in the industry \\
\hline
\end{tabular}

\begin{tabular}{|c|c|}
\hline \multicolumn{2}{|c|}{ Intellectual Capital } \\
\hline \multicolumn{2}{|c|}{ Human Capital: } \\
\hline HC 27 & Our employees are highly skilled \\
\hline HC 28 & Our employees are widely considered the best in our industry \\
\hline HC 29 & Our employees are experts in their particular jobs and functions \\
\hline HC 30 & Our employees are creative and bright \\
\hline HC 31 & Our employees develop new ideas and knowledge \\
\hline \multicolumn{2}{|c|}{ Social Capital: } \\
\hline SC 32 & $\begin{array}{l}\text { Our employees are skilled at collaborating with each other to diagnose and solve } \\
\text { problems }\end{array}$ \\
\hline SC 33 & Our employees share information and learn from one another \\
\hline SC 34 & $\begin{array}{l}\text { Our employees interact and exchange ideas with people from different areas of } \\
\text { the company }\end{array}$ \\
\hline SC 35 & $\begin{array}{l}\text { Our employees partner with customers, suppliers, alliance partners, etc. to } \\
\text { develop solutions }\end{array}$ \\
\hline SC 36 & $\begin{array}{l}\text { Our employees apply knowledge from one area of the company to problems and } \\
\text { opportunities that arise in another. }\end{array}$ \\
\hline \multicolumn{2}{|c|}{ Organizational Capital: } \\
\hline OC 37 & Our organization uses patents and licenses as a way to store knowledge \\
\hline OC 38 & Much of our organization's knowledge is contained in manuals, databases etc. \\
\hline OC 39 & Our organization's culture contains valuable ideas, ways of doing business etc. \\
\hline OC 40 & $\begin{array}{l}\text { Our organization embeds much of its knowledge and information in structures, } \\
\text { systems and processes }\end{array}$ \\
\hline
\end{tabular}




\begin{tabular}{|ll|}
\hline Learning Capability \\
\hline Experimentation \\
\hline EXP 41 & People here receive support and encouragement when presenting new ideas \\
\hline EXP 42 & $\begin{array}{l}\text { Initiatives often receive favourable responses here, so people are encouraged to } \\
\text { generate new ideas }\end{array}$ \\
\hline Risk-Taking & People are encouraged to take risks in this organization \\
\hline RT 43 & People often venture into unknown territory \\
\hline RT 44 & $\begin{array}{l}\text { It is part of the work of all staff to collect, bring back and report information about } \\
\text { what is going on outside of the company }\end{array}$ \\
\hline Interaction with External \\
\hline Inter 45 & $\begin{array}{l}\text { There are systems and procedures for receiving, collating, and sharing } \\
\text { information from outside of the company }\end{array}$ \\
\hline Inter 46 & $\begin{array}{l}\text { People are encouraged to interact with the environment (e.g. competitors, } \\
\text { customers) }\end{array}$ \\
\hline Inter 47 & Employees are encouraged to communicate \\
\hline \multicolumn{2}{|c|}{} \\
\hline Dialogue & There is free and open communication within our firm \\
\hline D 48 & Managers facilitate communication within our firm \\
\hline D 49 & Cross-functional teamwork is a common practice here in our firm \\
\hline D 50 & Policies are significantly influenced by the view of employees \\
\hline D 51 & People feel involved in main company decisions \\
\hline Participative Decision-Making \\
\hline P 52
\end{tabular}

\begin{tabular}{|c|c|}
\hline \multicolumn{2}{|c|}{ Technological Orientation: } \\
\hline TO 55 & Our products include high technology items \\
\hline TO 56 & New product ideas are technology-resourced in our firm \\
\hline TO 57 & Advanced technologies and methods are used to develop new products in our firm \\
\hline TO 58 & New product development process is directed by technical personnel \\
\hline TO 59 & New technologies are integrated into our firm rapidly \\
\hline TO 60 & Our firm is an initiator of the development of new technologies and products \\
\hline TO 61 & $\begin{array}{l}\text { We intend to develop new technologies in order to respond to the changing } \\
\text { expectations of our customers }\end{array}$ \\
\hline TO 62 & We have better technological knowledge than our competitors \\
\hline TO 63 & Our product development programs are more ambitious than our competitors' \\
\hline
\end{tabular}

\begin{tabular}{|ll|}
\hline Innovative Milieu: By locating in our location, our firm can \\
\hline IM 64 & $\begin{array}{l}\text { lower the costs of gaining access to inputs of production such as skilled labour, } \\
\text { specialist services }\end{array}$ \\
\hline IM 77 & $\begin{array}{l}\text { have privileged access to tacit knowledge that is unavailable or available at high } \\
\text { costs to firms located elsewhere }\end{array}$ \\
\hline IM 81 & \begin{tabular}{l} 
be more creative, more innovative and more orientated to technological creation \\
\hline IM 85
\end{tabular}$\quad$ collaborate with our customers, and suppliers to produce innovations \\
\hline
\end{tabular}

